\title{
ANALISA SISTEM ANTRIAN DENGAN METODE KOMPUTASI TURBO PASCAL
}

\author{
RINA OKTAVIYANTHI
}

Universitas Serang Raya, rinaokta@unsera.ac.id

\begin{abstract}
Abstrak. Sistem antrian yang terjadi di BRI cabang Rangkasbitung adalah model struktur antrian Multi Channel Single Phase (MCSP), yaitu sistem yang terdiri dari suatu barisan antrian dengan dua atau lebih fasilitas pelayanan yang dilakukan secara beruntun. Sedangkan tahap pelayanannya terdiri dari satu tahap (satu fase) pelayanan, dan unit-unit dalam antrian dilayani hanya berdasarkan urutan kedatangan, setiap unit diperlakukan dalam cara yang sama dan tak terbatas panjangnya antrian. Penelitian ini memokuskan pada dua hal yaitu: (1) bagaimana mengkaji variabel-variabel sistem antrian dan penentuan sensitivitas performance variabel-variabel tersebut dalam menghadapi perubahan desain dari sistem antrian pada BRI cabang Rangkasbitung secara matematis, dan (2) bagaimana membuat program dengan Turbo Pascal untuk menyelesaikan performance variabel-variabel sistem. Populasi dan sampel adalah semua pelanggan atau nasabah yang masuk dalam sistem antrian pada BRI Cabang Rangkasbitung. Data yang dikumpulkan adalah banyaknya kedatangan nasabah per hari selama 5 hari pengambilan data dan data pelayanan nasabah dimulai pada saat nasabah masuk sampai dengan selesai pengambilan atau penyetoran secara tunai. Dari hasil penggunaan program Turbo Pascal dengan asumsi kedatangan nasabah berdistribusi Poisson dan waktu pelayanan nasabah berdistribusi Eksponensial, diperoleh (1) rata-rata tingkat kedatangan (per 5 hari) $(\lambda)$ per jam adalah 311 , (2) rata-rata tingkat pelayanan (per 5 hari) ( $\mu$ ) per jam adalah 280, (3) rata-rata jumlah individu dalam antrian adalah $0.0000455,(4)$ rata-rata jumlah individu dalam sistem total adalah 1.1077, (5) rata-rata waktu dalam antrian adalah 0.000778 , (6) rata-rata waktu dalam sistem total adalah 66, (7) persentase rata-rata tingkat kegunaan fasilitas layanan adalah $15.82 \%$, (8) persentase rata-rata probabilitas tidak ada individu dalam antrian adalah $33.08 \%$, dan (9) persentase rata-rata probabilitas menunggu dalam antrian $0.011643 \%$.
\end{abstract}

Kata kunci: komputasi, teori antrian, turbo pascal

\section{Pendahuluan}

Dewasa ini bank merupakan salah satu unit pelayanan umum yang sangat penting. Jasa pelayanan bank ini berhubungan dengan kepuasan nasabah. Masalah antrian dapat menjadi salah satu faktor penentu kepuasan nasabah. Munculnya masalah antrian ini menurut Cogdill [1] disebabkan 
oleh kebutuhan akan layanan melebihi kemampuan (kapasitas) pelayanan atau fasilitas pelayanan, sehingga nasabah yang datang tidak segera mendapat layanan disebabkan kesibukan pelayanan. Pada pelayanan transaksi tunai (pengambilan dan penyetoran secara tunai) di BRI cabang Rangkasbitung, antrian adalah hal yang tidak dapat dihindarkan. Jika ditinjau dari model struktur antrian dan fasilitas pelayanan, maka sistem antrian yang terjadi di BRI cabang Rangkasbitung adalah model struktur antrian Multi Channel Single Phase (MCSP). Seperti yang diungkapkan oleh Perros [2], MCSP yaitu sistem yang terdiri dari suatu barisan antrian dengan dua atau lebih fasilitas pelayanan yang dilakukan secara beruntun. Sedangkan jika dilihat dari tahap pelayanannya, terdiri dari satu tahap (satu fase) pelayanan, dan unit-unit dalam antrian dilayani hanya berdasarkan urutan kedatangan, setiap unit diperlakukan dalam cara yang sama dan tak terbatas panjangnya antrian. Karena pekerjaan dasar pelayanan pada bank inilah yang kemudian mendasari banyak peneliti melakukan inovasi untuk meningkatkan indeks kepuasan nasabah.

Salah satu cara yang dapat digunakan untuk memecahkan masalah antrian adalah dengan teori antrian. Teori antrian adalah teori yang menyangkut studi matematis dan baris-baris penungguan. Secara umum, teori antrian berkaitan dengan pemodelan matematika dan analisis system [3]. Formasi ini merupakan fenomena yang sering terjadi jika kebutuhan akan suatu pelayanan melebihi kapasitas fasilitas pelayanan yang tersedia. Namun dengan kemajuan ilmu pengetahuan dan teknologi saat ini, banyak peneliti yang menggunakan kelebihan teknologi untuk melakukan analisa [4]. Tak terkecuali dalam masalah antrian ini, penganalisaan dapat menggunakan metode komputasi dengan bantuan Turbo Basic, Foxpro Fordos dan Visual Foxpro atau yang lainnya. Hal tersebut mendorong penulis untuk menganalisa data yang diperoleh dengan menggunakan metode komputasi berbantuan program Turbo Pascal. Program Turbo Pascal dipilih karena bahasa Pascal adalah bahasa pemrograman tingkat tinggi (high level language) yang cukup popular dan terstruktur (structured programming language) mendekati bahasa manusia sehingga lebih mudah dipahami dibandingkan dengan bahasa pemrograman lainnya, seperti bahasa C, bahasa Assembler, dan lain sebagainya [5].

Adapun yang menjadi tujuan penelitian ini, yakni:

1. Untuk menganalisa dan memperbaiki performance variablelvariabel sistem $\left(\bar{n}_{q}, \bar{n}_{t}, \bar{t}_{q}, \bar{t}_{t}, p_{n}, p_{0}, p_{w}, p\right)$, serta penentuan sensitivitas performance variabel-variabel dalam menghadapi perubahan-perubahan desain sistem $(\lambda, \mu, S, n)$.

2. Membuat program dengan Turbo Pascal untuk menyelesaikan performance variabel-variabel system.

\section{A. Hakekat Teori Antrian}

Analisis antrian memberikan informasi probabilitas yang dinamakan operating characteristic, yang dapat membantu mengambil keputusan dalam merancang fasilitas pelayanan antrian untuk mengatasi permintaan pelayanan yang fluktuatif secara random dan menjaga keseimbangan antara biaya pelayanan dan biaya menunggu [6].

Antrian (а queue) adalah suatu garis (waiting line) tunggu dari nasabah (satuan) yang memerlukan layanan dari satu atau lebih pelayanan (fasilitas pelayanan) [3]. Studi matematikal dari kejadian atau gejala garis tunggu ini disebut teori antrian. Kejadian garis tunggu timbul disebabkan oleh kebutuhan akan layanan melebihi kemampuan (kapasitas) pelayanan atau fasitas layanan, sehingga nasabah yang datang tidak bisa segera mendapat layanan disebabkan kesibukan pelayanan [7]. 


\section{B. Konsep-konsep Dasar Teori Antrian}

Konsep dasar teori antrian menurut Buzacott [8] dan Subagio [9] dapat dibedakan atas empat bagian, yaitu: (1) tujuan, (2) elemen pokok dalam sistim antrian, (3) struktur antrian, dan (4) model antrian.

1. Tujuan. Tujuan dasar model-model antrian adalah untuk meminimumkan total dua biaya, yaitu biaya langsung yang timbul karena penyediaan fasilitas pelayanan dan biaya tidak langsung yang timbul karena para individu harus menunggu untuk dilayani.

2. Elemen-elemen Pokok dalam Sistem Antrian. (a) Antrian yang memuat langganan atau satuan-satuan yang memerlukan pelayanan, dan (b) Fasiltas pelayanan yang memuat pelayanan dan saluran pelayanan.

3. Struktur Antrian

Ada 4 model struktur antrian yang umum terjadi dalam seluruh sistem antrian [2] [7] [9] [10], yaitu:

\section{a. Single Channel Single Phase}

Sistem ini adalah yang paling sederhana. Sistem ini terdiri dari antrian dan satu fase pelayanan (Gambar1)

\section{b. Multi Channel Single Phase}

Sistem ini terdiri satu barisan antrian dan dua atau lebih fasilitas pelayanan yang dilaksanakan secara beruntun (Gambar2)

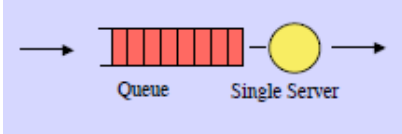

Gambar 1. Antrian tunggal, pelayanan tunggal

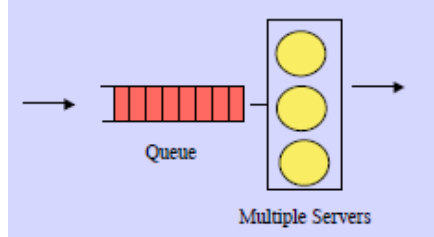

Gambar 2. Antrian tunggal, pelayanan ganda sejajar

c. Single Channel Multi Phase

Sistem ini terdiri dari satu antrian tunggal dan beberapa fase pelayanan. Setiap satuan datang dari satu antrian tunggal dan mengalami beberapa kali pelayanan secara beruntun (Gambar3).

\section{d. Multi Channel Multi Phase}

Sistem ini terdiri dari beberapa barisan dan beberapa fase pelayanan (Gambar4).

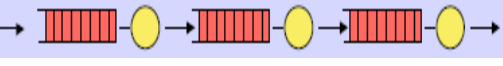

Gambar 3. Antrian tunggal, pelayanan ganda dalam seri

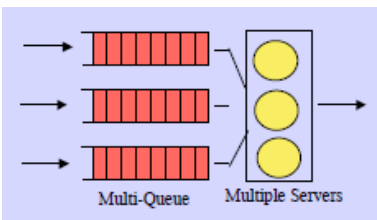

Gambar 4. Antrian ganda, pelayanan ganda

\section{Model-model Antrian}

a) Model M/M/1/I/I

Model ini biasanya dipakai pada sistem antrian single channel single phase yang mempunyai antrian tunggal dengan melalui satu fasilitas pelayanan. 


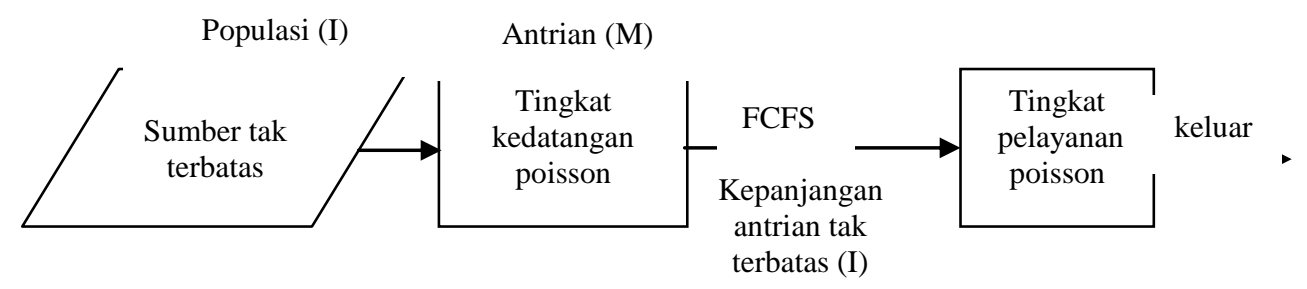

Gambar 5. Model antrian M/M/1/I/I

Rumus yang digunakan dalam menganalisis model ini adalah sebagai berikut:

$\begin{array}{lll}\bar{n}_{q}=\frac{(\lambda)^{2}}{\mu(\mu-\lambda)} & \bar{n}_{t}=\frac{\lambda}{(\mu-\lambda)} & \bar{t}_{q}=\frac{\lambda}{\mu(\mu-\lambda)} \\ \bar{t}_{t}=\frac{1}{\mu-\lambda} & \mathrm{P}_{n}=\left(1-\frac{\lambda}{\mu}\right)\left(\frac{\lambda}{\mu}\right)^{n} & P=\frac{\lambda}{\mu}\end{array}$

b) Model M/M/S/I/I

Model ini biasanya dipakai pada sistem antrian multi channel single phase yang mempunyai antrian tunggal dengan melalui beberapa fasilitas pelayanan.

Fasilitas pelayanan (M/S)

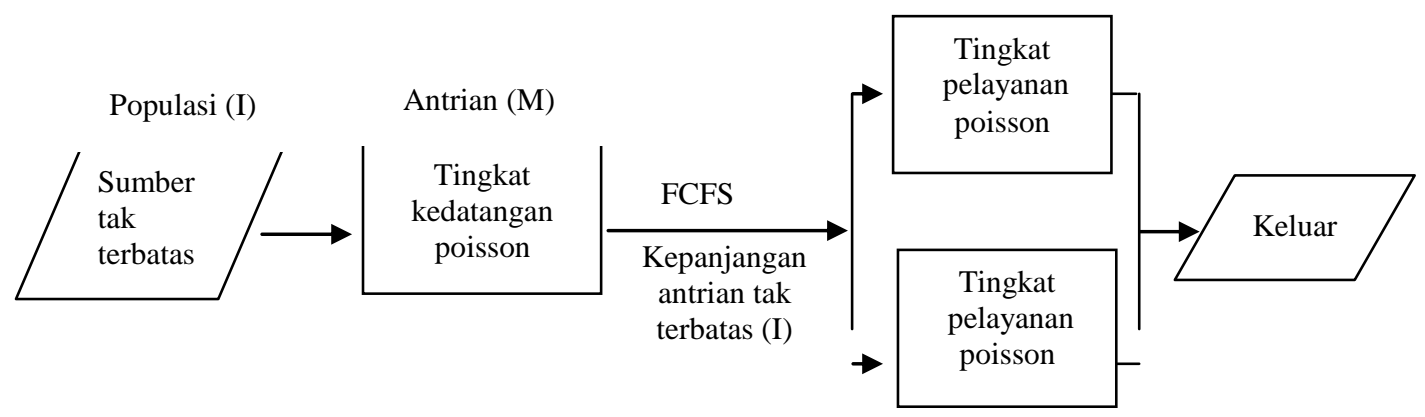

Gambar 6. Model antrian M/M/S/I/I

Rumus yang digunakan dalam menganalisis model ini adalah sebagai berikut:

$$
\begin{aligned}
& P=\frac{\lambda}{s \mu} \\
& p_{0}=\frac{1}{\sum_{n=0}^{s-1}\left[\frac{\left(\frac{\lambda}{\mu}\right)^{n}}{n !}\right]+\frac{\left(\frac{\lambda}{\mu}\right)^{s}}{s !\left(1-\frac{\lambda}{s \mu}\right)}} \\
& p_{w}=\left(\frac{\lambda}{\mu}\right)^{s} \frac{P_{0}}{s !\left[1-\left(\frac{\lambda}{s \mu}\right)\right]} \\
& \bar{n}_{q}=\frac{\lambda \mu\left(\frac{\lambda}{\mu}\right)^{s}}{(s-1) !\left(\mu(s \mu-\lambda)^{2}\right.} P_{o} \\
& \bar{t}_{q}=\frac{P_{o}}{\mu s(s !)\left(1-\left(\frac{\lambda}{s \mu}\right)\right)^{2}}\left(\frac{\lambda}{\mu}\right)^{s}
\end{aligned}
$$




$$
\begin{aligned}
& \bar{n}_{t}=\bar{n}_{q}+\frac{\lambda}{\mu} \\
& \bar{t}_{t}=\bar{t}_{q}+\frac{1}{\mu}
\end{aligned}
$$

\section{c) Model $\mathbf{M} / \mathbf{M} / \mathbf{I} / \mathbf{I} / \mathbf{F}$}

Model ini identik dengan model 1 , dengan perbedaan bahwa kepanjangan antrian adalah terbatas.

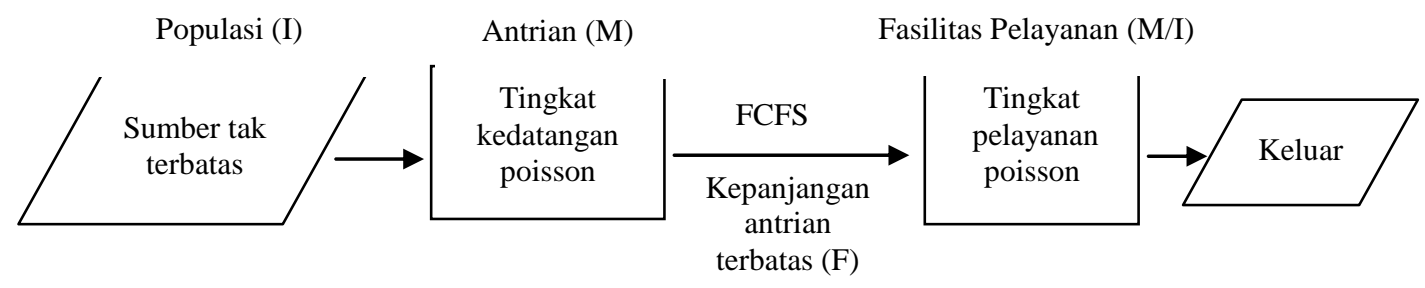

\section{Gambar 7. Model antrian M/M/I/I/F}

Untuk menganalisis model ini menggunkan rumus sebagai berikut:

$$
\begin{gathered}
\bar{n}_{q}=\left(\frac{\lambda}{\mu}\right)^{s}\left[\frac{1-Q\left(\frac{\lambda}{\mu}\right)^{Q-1}+Q-1\left(\frac{\lambda}{\mu}\right)^{Q}}{\left(1-\frac{\lambda}{\mu}\right)\left[1-\left(\frac{\lambda}{s \mu}\right)^{Q}\right]}\right] \bar{n}_{t}=\left(\frac{\lambda}{\mu}\right)\left[\frac{1-(Q+1)\left(\frac{\lambda}{\mu}\right)^{Q}+Q\left(\frac{\lambda}{\mu}\right)^{Q+1}}{\left[1-\left(\frac{\lambda}{\mu}\right)\right]\left[1-\left(\frac{\lambda}{\mu}\right)^{Q+1}\right]}\right] \\
\bar{P}_{n}=\left[\frac{1-\left(\frac{\lambda}{\mu}\right)}{1-\left(\frac{\lambda}{\mu}\right)^{Q+1}}\right]\left(\frac{\lambda}{\mu}\right)^{n}
\end{gathered}
$$

d) Model M/M/S/F/I

Model empat adalah sama dengan model 2, dengan perbedaan bahwa model ini mempunyai populasi yang terbatas.

Fasilitas Pelayanan (M/S)

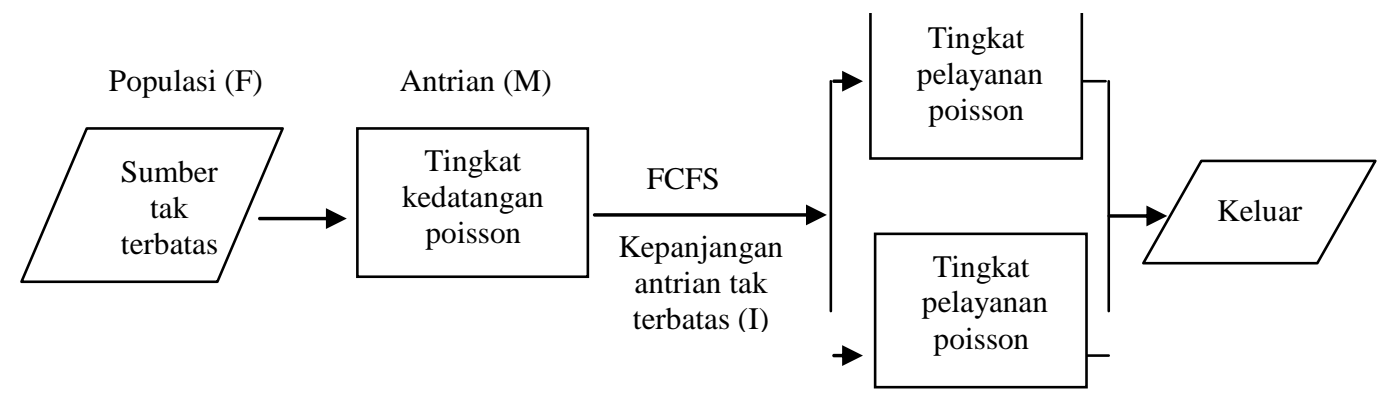

Gambar 8.Model antrian M/M/S/F/I

Untuk menganalisis model ini menggunkan rumus sebagai berikut: 


$$
\begin{gathered}
X=\frac{T}{T+U} \quad \bar{t}_{q}=\frac{\bar{t}_{q}(T+U)}{N-\bar{n}_{q}} \quad \bar{t}_{t}=\frac{\bar{t}_{q}(T+U)}{N-\bar{n}_{q}}+F \\
\bar{n}_{q}=N(1-F) \\
\bar{n}_{t}=N-J=\bar{n}_{q}+H \\
H=F N X \\
J=N F(1-X)
\end{gathered}
$$

Dilihat dari sistem antrian yang terjadi pada BRI cabang Rangkasbitung adalah struktur antrian Multi Channel Single Phase (MCSP), yaitu sistem yang terdiri dari suatu barisan antrian dan dua atau lebih fasilitas pelayanan yang dilakukan secara beruntun maka model antrian yang dipakai penulis dalam penelitian ini adalah model $\mathrm{M} / \mathrm{M} / \mathrm{S} / \mathrm{I} / \mathrm{I}$.

\section{Bahasa Pemrograman}

Bahasa pemrograman merupakan prosedur/ tata cara penulisan program. Louden (2003) menuturkan mengenai definisi bahasa pemrograman, "programming is a notation for communicating to a computer what we want it to do" [12]. Fungsi bahasa pemrograman adalah sebagai media untuk menyusun dan memahami serta sebagai alat komunikasi antara pemrogram dengan komputer. Secara umum terdapat empat kelompok bahasa pemrograman [13], yaitu:

1. Object Oriented Language (Visual dBase, Visual FoxPro, Delphi, Visual C)

2. High Level (seperti Pascal dan Basic)

3. Middle Level (seperti Bahasa C)

4. Low Level (seperti Bahasa Assembly)

Pascal merupakan salah satu bahasa pemrograman tingkat tinggi. Pemrograman tingkat tinggi menandakan bahwa Pascal banyak menggunakan bahasa manusia dalam penulisan sintaksnya. Turbo Pascal merupakan program compiler. Compiler yaitu program yang menerjemahkan tulisan berupa kode program menjadi bahasa mesin yang dapat dimengerti komputer. Proses yang dilakukan disebut compile atau compiling [13]. Suatu program dapat di-compile dengan menggunakan kombinasi tombol Alt + F9. Sementara untuk menjalankan program, tombol yang digunakan adalah Ctrl + F9. Jika selama proses compile terdapat error atau kesalahan dalam penulisan program, maka Turbo Pascal akan memberitahukan letak kesalahan tersebut sehingga pengguna dapat meperbaikinya di halaman editor. Turbo Pascal merupakan bahasa yang case insensitive yang artinya penulisan dalam huruf kapital maupun huruf kecil tidak dipermasalahkan.

Dalam bahasa Pascal terdapat beberapa jenis tipe data yang biasa digunakan untuk sebuah variabel atau konstanta pada program. Secara umum, tipe data dalam pemrograman Pascal adalah:

1. Tipe data sederhana, maksudnya adalah tipe data yang digunakan standar (standard data type) dan tipe data didefinisikan pengguna (user defined data type).

2. Tipe data terstruktur (array, record, set, file)

3. Tipe data penunjuk

Penggunaan program Turbo Pascal dalam penelitian ini dikarenakan kelebihan-kelebihannya, yaitu:

1. Tipe data standar 
2. User defined data type, programer/ pengguna dapat membuat tipe data lain yang diturunkan dari tipe data standar.

3. Strongly-typed, programer/ pengguna harus menentukan tipe data dari suatu variabel, dan variabel tersebut tidak dapat dipergunakan untuk menyimpan tipe data selain dari format yang ditentukan.

4. Terstruktur, memiliki sintaks yang meungkinkan penulisan program dipecah menjadi fungsi-fungsi kecil (procedure dan function) yang dapat dipergunakan berulang-ulang.

5. Sederhana dan ekspresif, memiliki struktur sederhana dan sangat mendekati bahasa manusia (bahasa Inggris) sehingga mudah dipelajari dan dipahami.

Penelitian ini dilakukan pada BRI cabang Rangkasbitung yang pengambilan datanya dilakukan selama 5 hari kerja. Dalam penelitian ini yang menjadi populasi dan sampel adalah semua pelanggan atau nasabah yang masuk dalam sistem antrian pada BRI cabang Rangkasbitung. Penelitian ini adalah penelitian matematika yang termasuk dalam kategori pengembangan metode matematika terapan yang dikombinasikan dengan aplikasi secara langsung. Dengan demikian metode yang digunakan adalah metode analisis matematik dengan menggunakan rumus-rumus model antrian yang sesuai. Pada awalnya perhitungan di lakukan secara menual (perhitungan biasa kemudian dengan menggunakan metode komputasi. Dalam metode komputasi ini, peneliti menggunakan bahasa pemrograman Turbo Pascal yakni ini merumuskan langkah-langkah penyelesaian (algoritma) dari tiap-tiap rumus model antrian sehingga dapat dijalankan oleh komputer.

Untuk mengumpulkan data yang diperlukan dalam penelitian ini, penulis menggunakan teknik pengumpulan data sebagai berikut:

\section{a. Observasi}

Dimana penulis memperoleh data dengan cara mengamati dan mencatat secara langsung data yang diperlukan (waktu kedatangan, waktu dimulainya pelayanan dan waktu selesai pelayanan) dari setiap individu dalam antrian pada BRI cabang Rangkasbitung untuk setiap pelayanan.

Setelah data diperoleh, data tersebut akan dianalisis dengan langkahlangkah sebagai berikut:

\section{a. Menentukan Parameter}

Parameter yang diperlukan dalam analisis data antrian meliputi:

1) jumlah individu pada suatu waktu (n)

2) jumlah fasilitas pelayanan (S)

3) rata-rata tingkat kedatangan per satuan waktu $(\lambda)$

4) rata-rata tingkat pelayanan per satuan waktu $(\mu)$

\section{b. Menentukan Karakteristik Data}

Setelah data dikumpulkan dan ditentukan parameter-patameternya, maka data akan dianalisis secara matematik untuk menentukan karakteristik variabel data tersebut yang meliputi :

1) rata-rata jumlah individu dalam antrian $\left(\bar{n}_{q}\right.$

2) rata-rata jumlah individu dalam sistem total ( $\eta_{t}$

3) rata-rata waktu dalam antrian $\left(\bar{\phi}_{q}\right.$

4) rata-rata waktu dalam sistem total $\left(\bar{j}_{t}\right.$

5) tingkat kegunaan fasilitas pelayanan $(P)$

6) probabilitas tidak ada individu dalam antrian $\left(P_{0}\right)$

7) probabilitas menunggu dalam antrian $\left(P_{\mathrm{w}}\right)$ 


\section{Hasil - Hasil Utama}

\section{a) Sistem Antrian Dan Solusi Yang Dilakukan}

Antrian yang terjadi pada BRI cabang Rangkasbitung merupakan masalah yang sering terjadi bagi para nasabah yang hendak melakukan transaksi. Antrian ini terjadi pada awal bulan dimana pada tanggal-tanggal tersebut merupakan saat-saat pengambilan gaji/ dana pensiunan dan saat-saat dimana para nasabah banyak melakukan transaksi pengiriman maupun pengambilan uang. Antrian ini terjadi karena jumlah nasabah yang datang setiap hari sangat banyak dimana jumlahnya lebih dari 500 orang per hari (perdasarkan data pengamatan). Sedangkan jumlah teller yang tersedia sangat terbatas dan tidak dioptimalkan secara baik.

Pada BRI cabang Rangkasbitung, setiap nasabah yang datang khususnya nasabah yang melakukan penyetoran tunai dan penarikan tunai menunggu untuk menerima pelayanan dari kasir, karena jumlah nasabah yang datang setiap hari cukup banyak maka teller yang difungsikan sebanyak 7 teller (multi channel).

b) Jumlah Kedatangan dan Pelayanan

Dari hasil observasi yang dilakukan oleh peneliti selama 5 hari (2-6 September 2013) dimana pada tanggal tersebut jumlah kedatangan cukup besar maka diperoleh data jumlah kedatangan sebagai berikut:

Tabel .1

Data Jumlah Kedatangan dan Pelayanan

\begin{tabular}{|l|c|c|c|}
\hline $\begin{array}{c}\text { Waktu } \\
\text { Observasi }\end{array}$ & $\begin{array}{c}\text { Jumlah Kedatangan } \\
\text { (Unit) }\end{array}$ & $\begin{array}{c}\text { Jumlah yang } \\
\text { Dilayani (Unit) }\end{array}$ & $\begin{array}{c}\text { Jumlah Penolakan } \\
\text { (Balking) (Unit) }\end{array}$ \\
\hline Hari I & 392 & 334 & 58 \\
\hline Hari II & 463 & 432 & 31 \\
\hline Hari III & 564 & 480 & 84 \\
\hline Hari IV & 317 & 299 & 18 \\
\hline Hari V & 441 & 417 & 24 \\
\hline Jumlah & 2177 & 1962 & 71.67 \\
\hline Rata-rata & 435.4 & 392 & \\
\hline
\end{tabular}

(Data diambil pada tanggal 2-6 September 2013)

Jumlah kedatangan nasabah tertinggi terjadi pada hari ketiga (waktu pengamatan) yakni sebanyak 564 orang nasabah dan jumlah penolakan tertinggi juga terjadi pada hari kedua yakni 84 orang. Sedangkan jumlah kedatangan nasabah terendah terjadi pada hari keempat (waktu pengamatan) sebanyak 317 orang dan jumlah penolakan terendah juga terjadi pada hari keempat yaitu 18 orang. Dengan demikian dapat diketahui bahwa rata-rata jumlah kedatangan sebanyak 435.4 orang per hari. Sedangkan rata-rata jumlah nasabah yang dilayani sebanyak 392 per hari dan yang keluar dari sistem sebelum menerima pelayanan sebanyak 71.67 per hari.

c) Rata-rata Tingkat Kedatangan dan Tingkat Pelayanan

Dari hasil rata-rata waktu antar kedatangan dan rata-rata waktu pelayanan pada lampiran, maka tingkat kedatangan dan tingkat pelayanan pada 7 teller yang ada pada BRI cabang Rangkasbitung dapat dilihat pada tabel berikut:

Tabel. 2

Rata-Rata Tingkat Kedatangan dan Tingkat Pelayanan

\begin{tabular}{|l|c|c|}
\hline $\begin{array}{c}\text { Waktu } \\
\text { Observasi }\end{array}$ & $\begin{array}{c}\text { Rata-Rata Tingkat } \\
\text { Kedatangan }(\lambda) \text { (unit per } \\
\text { jam })\end{array}$ & $\begin{array}{c}\text { Rata-Rata Tingkat } \\
\text { Pelayanan }(\mu) \text { (unit per jam) }\end{array}$ \\
\hline Hari I & 56 & 48 \\
\hline Hari II & 66 & 62 \\
\hline
\end{tabular}




\begin{tabular}{|l|c|c|}
\hline Hari III & 81 & 69 \\
\hline Hari IV & 45 & 43 \\
\hline Hari V & 63 & 60 \\
\hline Rata-rata & 311 & 280 \\
\hline
\end{tabular}

Berdasarkan tabel di atas maka terlihat bahwa rata-rata tingkat kedatangan per hari paling tinggi terjadi pada hari ketiga yaitu sebanyak 81 orang per jam dengan rata-rata tingkat pelayanan per hari 69 orang per jam. Sedangkan rata-rata tingkat kedatangan per hari paling rendah terjadi pada hari keempat yaitu sebanyak 45 orang per jam dengan ratarata tingkat pelayanan per hari sebanyak 43 unit per jam.

Dengan demikian dapat dijelaskan bahwa rata-rata tingkat kedatangan dari 5 hari observasi (pengamatan) adalah 311 per jam per hari dengan rata-rata tingkat pelayanan adalah 280 per jam per hari.

Dilihat dari struktur antrian yang terjadi pada teller-teller pada BRI cabang Rangkasbitung adalah struktur antrian multi channel single phase yakni sistem yang terdiri dari satu barisan antrian dan dilayani lebih dari satu fasilitas pelayanan, maka rumus pada model antrian pelayanan ganda ini adalah M/M/S/I/I.

Berdasarkan hasil uraian di atas maka hasil analisis data dengan metode komputasi Turbo Pascal adalah sebagai berikut.

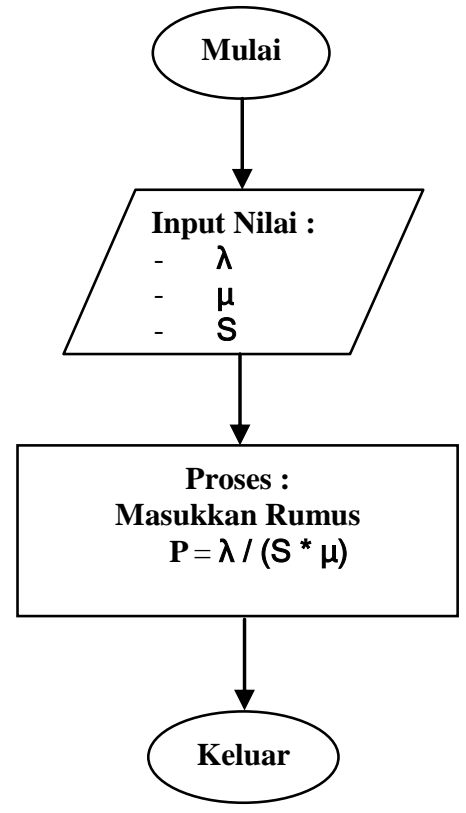

Gambar 9. Flowchart Menghitung Nilai P

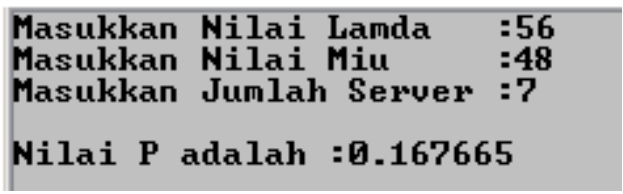

Gambar 10. Hasil Run Nilai P Hari 1 


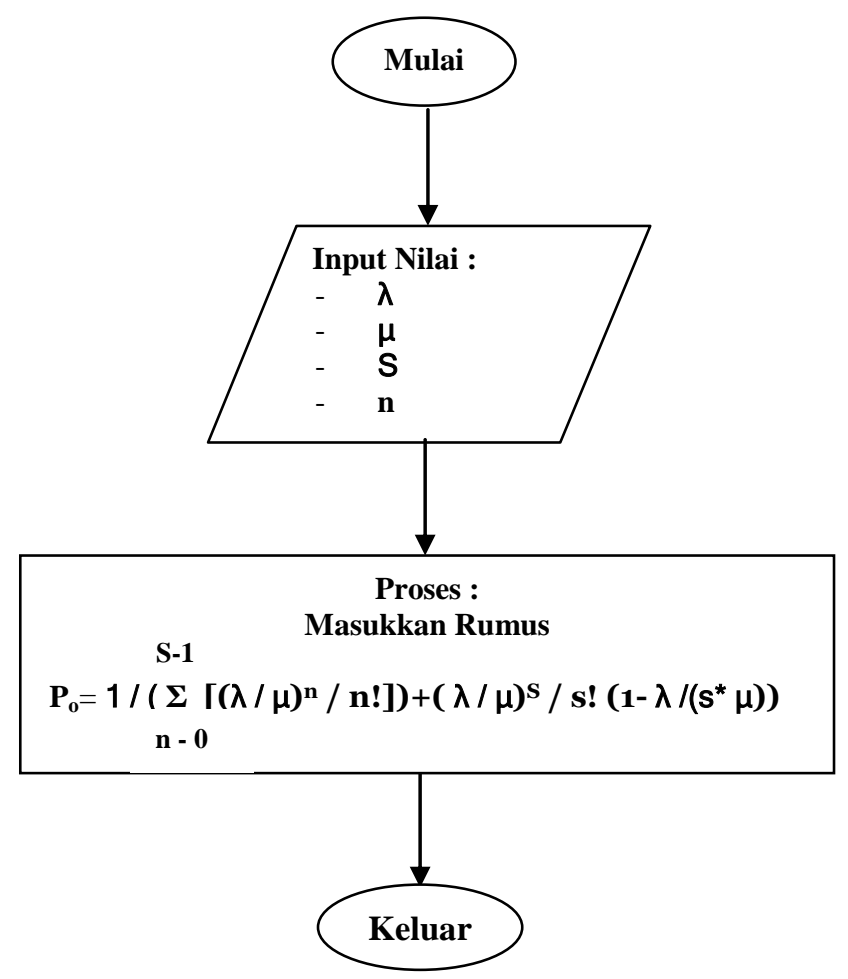

Gambar 11. Flowchart Menghitung Nilai $P_{o}$

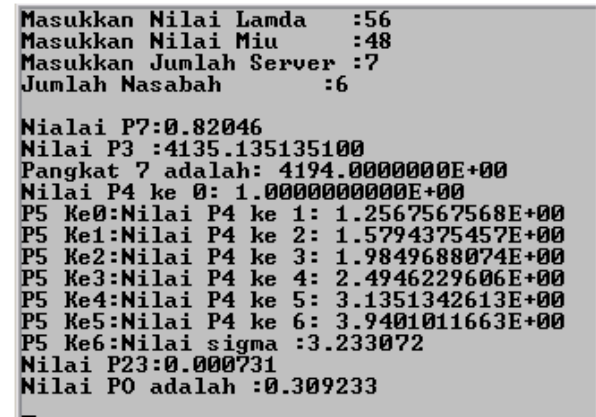

Gambar12. Hasil Run Nilai $P_{o}$ Hari 1

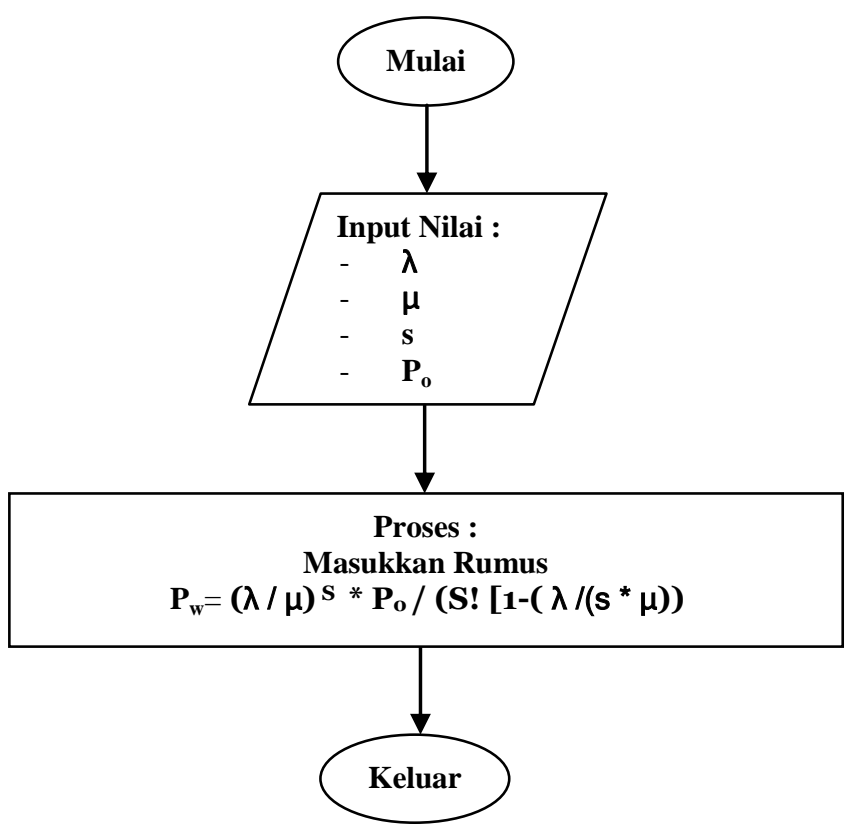

Gambar 13. Flowchart Menghitung Nilai $P_{W}$ 
Masukkan Nilai Lamda $\quad: 56$

Masukkan Nilai Miu :

Masukkan Jumlah Server :?
Masukkan Nilai Po

Dibawah ini adalah hasil perhitung rumus secara terpisah

Nilai P4 :0.832335

Nilai P3 $: 50040.90000$

:Pangkat adalah : 1.173653

NILAI PW

Nilai PW adalah :0.00015665

Gambar 14. Hasil Run Nilai $P_{W}$ Hari 1

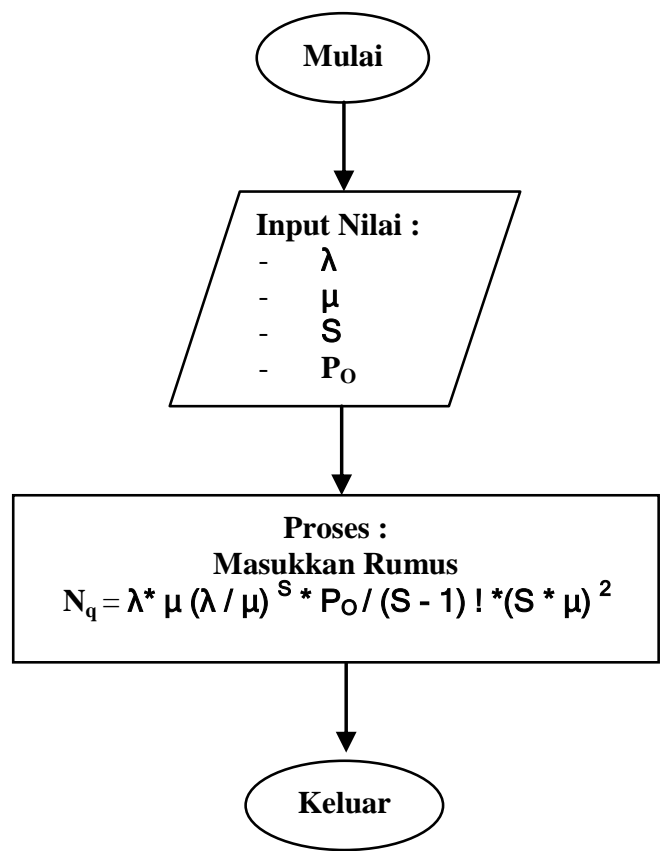

Gambar 15. Flowchart Menghitung Nilai nq

\begin{tabular}{|c|c|c|}
\hline $\begin{array}{l}\text { Masukkan } \\
\text { Masukkan } \\
\text { Masukkan } \\
\text { Masukkan }\end{array}$ & $\begin{array}{l}\text { Nilai Lamda } \\
\text { Nilai Miu } \\
\text { Jumlah Server } \\
\text { Nilai Po }\end{array}$ & $\begin{array}{l}: 56 \\
: 48 \\
: ? \\
: 0.399233\end{array}$ \\
\hline $\begin{array}{ll}\text { Nilai } & \text { P3 } \\
\text { Nilai } & \text { P2 } \\
\text { Nilai } & \text { P5 } \\
\text { Nilai } & \text { P1 } \\
\text { Nilai } & \text { P4 }\end{array}$ & $\begin{array}{l}=5040.090909 \\
=4194.090909 \\
=137746.090909 \\
=1.173653 \\
=0.832335\end{array}$ & \\
\hline Nilai NQ & adalah :0.0000 & 9455 \\
\hline
\end{tabular}

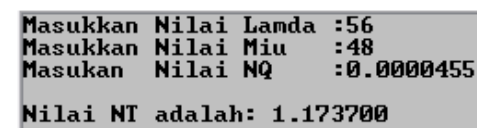

Gambar 17. Hasil Run Nilai nt Hari 1

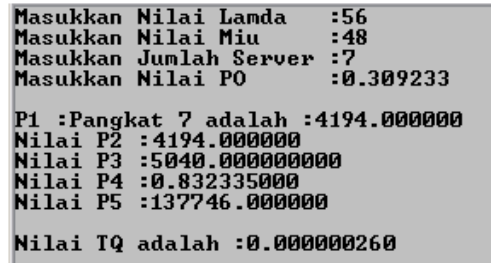

Gambar 18. Hasil Run Nilai tq Hari 1 


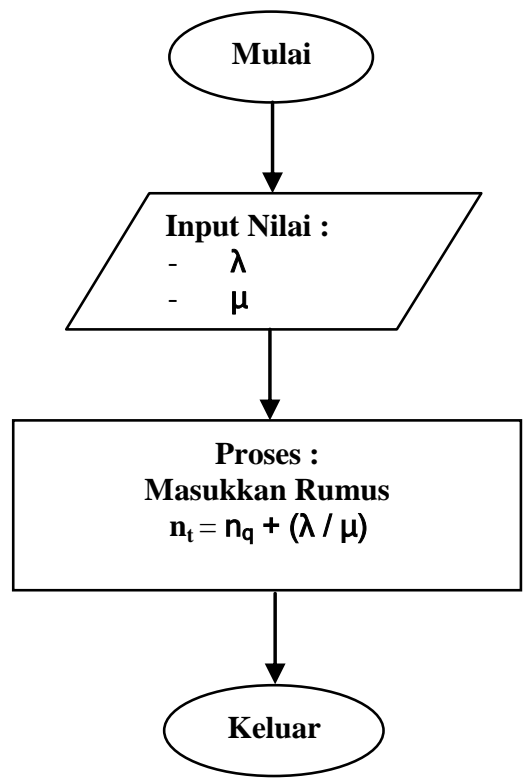

Gambar 19. Flowchart Menghitung Nilai nt

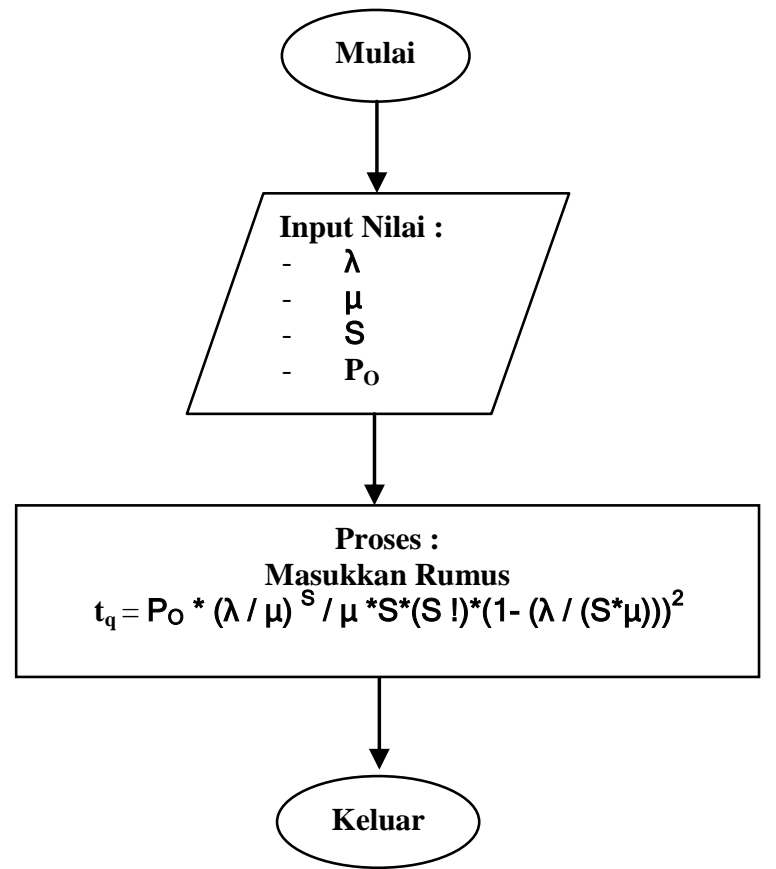

Gambar 20. Flowchart Menghitung Nilai tq

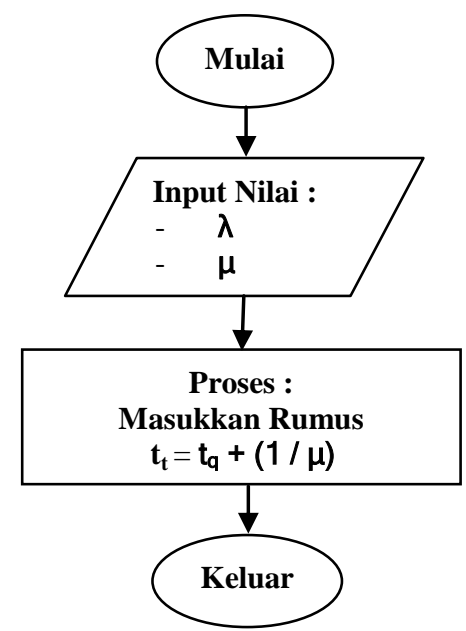

Gambar 21. Flowchart Menghitung Nilai $t_{t}$ 


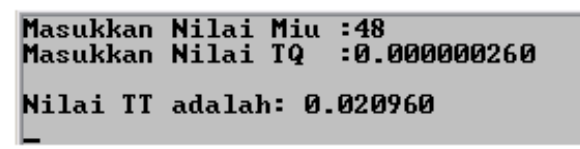

Gambar 21. Hasil Run Nilai $t_{t}$ Hari 1

Dengan perhitungan yang sama, maka hasil analisa data pada hari pertama sampai hari kelima dapat disajikan dalam tabel berikut :

Tabel. 3

Hasil Analisa Data

\begin{tabular}{|l|c|c|c|c|c|c|c|}
\hline $\begin{array}{c}\text { Waktu } \\
\text { Observasi }\end{array}$ & $\overline{n_{q}}$ (unit) & $\begin{array}{c}\overline{n_{t}} \\
\text { (unit) }\end{array}$ & $\overline{t_{q}}$ (detik) & $\begin{array}{c}\overline{t_{t}} \\
\text { (detik) }\end{array}$ & $p(\%)$ & $p_{0}(\%)$ & $p_{w}(\%)$ \\
\hline Hari I & 0.0000455 & 1.1737 & 0.000937 & 75 & 16.77 & 30.92 & 0.015665 \\
\hline Hari II & 0.0000236 & 1.0718 & 0.000666 & 58 & 15.31 & 34.24 & 0.009346 \\
\hline Hari III & 0.0000459 & 1.1750 & 0.000653 & 53 & 16.79 & 30.88 & 0.015766 \\
\hline Hari IV & 0.0000218 & 1.0602 & 0.000952 & 84 & 15.15 & 34.64 & 0.00878 \\
\hline Hari V & 0.0000214 & 1.0576 & 0.000681 & 60 & 15.11 & 34.73 & 0.008655 \\
\hline Rata-Rata & 0.0000316 & 1.1077 & 0.000778 & 66 & 15.82 & 33.08 & 0.011643 \\
\hline
\end{tabular}

Dari hasil analisa data pada tabel di atas dapat dijelaskan bahwa:

1. Rata-rata jumlah nasabah dalam antrian untuk setiap hari pelayanan adalah 0.0000316 unit. Artinya bahwa dalam setiap hari pelayana, ratarata jumlah nasabah yang menunggu untuk mendapatkan pelayanan sangat kecil atau tidak terjadinya antrian.

2. Rata-rata jumlah nasabah dalam sistem untuk setiap hari pelayanan adalah 1.1077 unit. Artinya bahwa hanya ada satu orang nasabah yang sedang berada dalam sistem dan nasabah tersebut sementara dilayani.

3. Rata-rata waktu menunggu dalam antrian untuk setiap hari pelayanan adalah 0.000778 detik

4. Rata-rata waktu menunggu dalam sistem untuk setiap hari pelayanan adalah 66 detik

5. Rata-rata tingkat kesibukan kasir pada setiap hari pelayanan adalah $15.82 \%$ dari waktunya

6. Probabilitas tidak ada nasabah dalam sistem untuk setiap hari pelayanan adalah $33.08 \%$ per hari

7. Probabilitas menunggu dalam antrian untuk setiap hari pelayanan adalah $0.011643 \%$ per hari.

Berdasarkan hasil observasi yang dilakukan oleh peneliti selama 5 hari menunjukkan bahwa ke tujuh teller tersebut selalu beroperasi pada setiap hari kerja. Namun demikian dalam membarikan pelayanan kepada para nasabah, ketujuh teller tersebut tidak bekerja secara optimal pada jam kerja. Hal ini diakibatkan karena pada saat-saat tertentu teller-teller tersebut melakukan sortir dan juga melakukan kegiatan lain (seperti istirahat makan siang yang dilakukan secara bergantian oleh para teller).

Hasil perhitungan yang menunjukkan bahwa nq, nt, tq, tt sangat kecil dan tingkat kesibukan kasir yang sangat kecil yakni $15.82 \%$ dengan probabilitas menunggu dalam antrian setiap hari pelayanan adalah 0.011643 $\%$. Hal ini terjadi karena waktu-waktu yang hilang dari beberapa orang teller ini diabaikan, sehingga jumlah teller (S) tetap dilihat beroperasi penuh. Hal yang demikian menunjukkan bahwa rumus-rumus teori antrian sangat terbatas dalam mengkaji masalah-masalah antrian yang terjadi dalam kehidupan, sehingga teknik simulasi sangat tepat untuk digunakan. Dari hasil analisa data yang dilakukan menunjukkan bahwa rata-rata waktu 
menunggu dalam antrian sangat kecil. Hal ini sangat tidak sesuai dengan kenyataan sebenarnya yang terjadi pada Kantor Bank BRI cabang Rangkasbitung, dimana banyak nasabah yang menunggu dalam waktu yang cukup lama. Dilihat jumlah teller yang tersedia yakni sebanyak 7 teller, maka penambahan fasilitas pelayanan bukan merupakan satu-satunya jalan untuk mengatasi masalah antrian yang terjadi di Kantor bank BRI cabang Rangkasbitung. Dengan demikian, maka solusi yang seharusnya diambil oleh pihak BRI cabang Rangkasbitung adalah dengan mengoptimalkan kinerja dari ke 7 teller yang ada. Analisis dari mengoptimalkan 7 teller yang ada pada jam kerja (kas), karena dari hasil perhitungan dengan 7 orang teller tersebut sudah menunjukan rata-rata waktu menunggu dalam antrian bagi tiap nasabah pun sangat kecil yakni $0.011643 \%$.

\section{Kesimpulan}

Berdasarkan uraian-uraian pada bab-bab sebelumnya maka penulis dapat menarik beberapa simpulan sebagai berikut:

1) Jika sistem bekerja dengan menggunakan 7 teller, namun tidak dioptimalkan dengan baik pada jam kerja (ada waktu kosong yang tidak digunakan), maka banyak nasabah yang menunggu dalam waktu yang cukup lama dan ada beberap orang nasabah yang meninggalkan sistem sebelum dilayani.

2) Jika sistem bekerja dengan menggunakan 7 teller yang bekerja secara optimal pada jam kerja, maka tingkat kesibukan teller sebesar 15,50\% dari waktunya per hari, dan rata-rata menunggu bagi tiap nasabah sangat kecil atau dianggap tidak ada artinya nasabah yang datang tidak mengalami antrian.

3) Performance variable-variabel akan lebih baik jika sistem pelayanan pada Kantor Bank BRI cabang Rangkasbitung difungsikan 7 teller yang bekerja secara optimal.

4) Dalam mengkaji masalah-masalah antrian yang terjadi dalam kehidupan, penerapan rumus-rumus antrian kadang kala tidak sesuai dengan kenyataan yang terjadi. Hal ini menunjukan bahwa rumus antrian mempunyai keterbatasan dalam mengkaji masalah antrian.

5) Perhitungan performance variabel sistem dapat dilakukan secara manual (perhitungan biasa) maupun dengan mengggunakan metode komputasi dimana perhitungannya dapat dilakukan dengan cepat.

\section{Referensi}

[1] Cogdil, T., Monticino, M, 2007, Analysis of Teller Service Times in Retail Banks, CS-BIGS, Volume 1, Issue 1, pp. 15-25.

[2] Perros, Harry, 2010, Queuing Theory - A Primer, Retrieved in: http://www4.ncsu.edu/ hp/SSME_QueueingTheory.pdf [Diunduh 18 Desember 2013]

[3] Cooper, Robert B., 2000, Encyclopedia of Computer Science Fourth Edition, Los Angeles: Groves Dictionaries Inc.

[4] Al-Jumaily, Ahmed S. A., Al-Jobori, Huda K. T., 2011, Automatic Queuing Model for Banking Applications, International Journal of Advanced Computer Science and Applications, Volume 2, No. 7.

[5] Ben-Ari, M., 2006, Understanding Programing Languages, Rehovot: Weizmann Institute of Science Copyright.

[6] Tabari, M., Kanani, Y. G., Divkolaii, M. S., Moghaddam, R. T., 2012, 
Allpication of The Queuing Theory to Human Resource Management, World Applied Sciences Journal, Volume 17, Issue 9, pp 1211-12118.

[7] Stallings, William, 2000, Queuing Analysis: Handbook, United States of America: Massachusetts Institute of Technology.

[8] Buzacott, John A., 2003, Queuing Theory and Its Applications, Canada: York University.

[9] Subagio, P., Asri, M., Handoko, H.T., 2010, Dasar-dasar Operations Research, Edisi 2. Yogyakarta: BPFE.

[10] Nafees, Azmat, 2007, Queuing Theory and Its Application: Analysis of The Sales Checkout Operation in ICA Supermaket, Hogskolan Dalarna: University of Dalarna.

[11] Louden, Kenneth C., 2003, Programming Languages: Principle and Practice $2^{\text {nd }}$ Edition, Pacific Grove, Calif: Cengage Learning.

[12] Istvan, J., 2011, Programming Languages, Hungarian: EHIB Copyright. 